\title{
Phytochemical and Histochemical Screening of Toxic Plant Based on Knowledge of Tengger Tribe in Ngadiwono Village, Pasuruan
}

\author{
Anggraeni In Oktavia ${ }^{1 *}$, Jati Batoro², Serafinah Indriyani \\ ${ }^{1}$ Master Program of Environmental Management and Development, Graduate School, University of Brawijaya, Malang, \\ Indonesia \\ ${ }^{2}$ Department of Biology, Faculty of Mathematics and Natural Sciences, University of Brawijaya, Malang, Indonesia
}

\begin{abstract}
Around hundreds of plant's species have been confirmed to produce toxic that could endanger the life of human or domestic animals. Some of those plants have potentials to be developed as medicine. The objective of this study is to reveal the secondary metabolite content of toxic plants mentioned by Tengger tribe on Ngadiwono village through phytochemical and histochemical screening test. This study was conducted on Ngadiwono village, Tosari district, Pasuruan Regency. Informants were selected using snowball method by following the information of key person ( $\mathrm{n}$ informant=14). Plants were selected and collected according to the local knowledge, then was analyzed qualitatively for its secondary metabolite content through phytochemical and histochemical screening test. The results showed that there are 8 plant species categorized as toxic by local people, including Bedor (Girardinia palmata), Kecubung Bunga Kuning (Brugmansia suaveolens), Kecubung Bunga Putih (Brugmansia suaveolens), Jarak (Ricinus communis), Terpasan Kuning (Cestrum elegans), Terpasan Merah (Cestrum elegans), Kudisan (Euphorbia pulcerrima), and Ciplukan (Physalis peruviana). The phytochemical result indicated that all toxic plants mentioned by the local people contain alkaloid substancess, while histochemical test showed that alkaloid substances were found in leaf trichomes, except in Terpasan Merah (Cestrum elegans).
\end{abstract}

Keywords: Fitochemical, Histochemical, Tengger Tribe, Toxic Plant.

\section{INTRODUCTION}

Most of the Tengger Tribe live by depending on the environment, including the utilization of plants and animals' biodiversity [1]. The knowledge of Tengger tribe about land and resource management is mainly affected by history, custom, and available resources [2]. The biological resources utilized by Tengger Tribe is including plants that have been utilized by human all over the world for a long time. Therefore, the interaction between human and plant is very important [3].

The knowledge of plants becomes very important recently along with the appearance of many kinds of diseases that threaten the human life. For example is the production of new medicines developed from coumpounds in plants. There are more than hundreds toxic plants, and some of them have potentials to be developed as medicine. Some species of toxic plants also utilized as pest control, such as nicotine in Nicotiana sp., seed extract of Baringtonia sp., and rotenoid in Derris spp. [4]. Chondodendron tumentosum

\footnotetext{
* Correspondence address: Anggraeni In Oktavia Email : anggraeni_oktavia@yahoo.com Address : Graduate Program, University of Brawijaya, Mayjen Haryono 169, Malang 65145.
}

contains of toxic alkaloid substancess called DTubocurarine. This toxic usually used by Indian society in Amazon to create poisoned arrows. Further, that substances is developed as muscle relaxant for surgery [5]. Surprisingly, all of those natural substancess become the basic for developing new medicine with a better quality. Reflecting the potency of secondary metabolite in toxic plants as revealed by previous study, therefore the aim of this study is to identify secondary metabolite in toxic plants according to the information from Tengger tribe in Ngadiwono village.

\section{MATERIALS AND METHODS Study Area}

This study was performed on Ngadiwono village, Tosari district, Pasuruan regency, East Java, Indonesia $\left(34^{\circ} 20^{\prime} 35.29^{\prime \prime} \mathrm{E}-35^{\circ} 09^{\prime} 27.04^{\prime \prime} \mathrm{E}\right.$ and latitudes $\left.0^{\circ} 05^{\prime} 19.12^{\prime \prime} \mathrm{N}-0^{\circ} 53^{\prime} 53.81^{\prime \prime} \mathrm{N}\right)$. Ngadiwono village is a buffer zone of Bromo Tengger Semeru National Park that comprised of 4 subdistricts: Ledoksari, Krajan, Ketuwon, and Banyu Meneng. Total area of the village is 639.03 ha. The distance between settlement area and forest is $2 \mathrm{~km}$. The minimum temperature reached $10^{\circ} \mathrm{C}$. Total number of male is 1097 individual, while female is 1474 individual, and the population density is 402 [6]. 


\section{Data Collection}

Data of toxic plant species was collected using semi-structured and in-depth interview. Fourteen informants were determined using snowball method. The researchers were accompanied by local people during data and sample collection. Data collection was terminated if it already got saturated data [7]. Stems, leaves, seeds, and flowers were collected for each species. Secondary metabolite test was conducted by following the procedure described below.

\section{Sample Preparation}

Leaves were dried using oven in the temperature of $60^{\circ}$ for 2 days. While seeds were dried using oven in the temperature of $60^{\circ}$ for 3 days.

\section{Alkaloid Test}

Two grams of sample powder were extracted using small amount of chloroform. Sample was then added with $10 \mathrm{~mL}$ of chloroform-ammonia and was filtered. The collected filtrate was added with drops of $\mathrm{H}_{2} \mathrm{SO}_{4} 2 \mathrm{M}$, homogenized until it formed 2 layers. Acid layer (colorless) was moved into three new glasses reaction. Each solvent was tested using drops of Dragendorf, Mayer, and Wagner reagents. The results were categorized as positive if the solvent forming precipitate with color of orange (Dragendorf), yellowish white (Mayer), and brown (Wagner) [8].

\section{Flavonoid Test}

Samples were soaked in $\mathrm{N}$-Hexane and filtered. The residue was added with $\mathrm{N}$-Hexane and filtered. This procedure was conducted repeatedly until the filtrate color turned into colorless. Then, filtrate was added with methanol, filtered, added concentrated $\mathrm{HCl}$ and $\mathrm{Mg}$ powder. If the filtrate form red brick precipitate, then the plant positively contains flavonoid [8]

\section{Terpenoid and Steroid Test}

Samples were soaked in $\mathrm{N}$-Hexane and filtered. Then, filtrate was evaporated until forming residue. Filtrate was then added with chloroform $0.5 \mathrm{~mL}$, acetic acid anhydrous $0.5 \mathrm{~mL}$, and concentrated $\mathrm{H}_{2} \mathrm{SO}_{4}$ 1-2 mL. If it forms reddish purple precipitate, then the plant positively contains terpenoid. In contrary, green precipitation means that the plant positively contains steroid [9].

\section{Tannin and Saponin Test}

Samples were soaked in $\mathrm{N}$-Hexane, filtered, and added with $\mathrm{N}$-Hexane until its color turned into green. Then, filtrate was added methanol, filtered, added ethanol, and filtered again. Ethanol filtrate was divided into two tubes. The first tube was added with $\mathrm{FeCl}_{3} 3$. If the filtrate turns its color into blackish green, then the plant positively contains tannin. The second tube was heated, then shaken. If it produces foam, then the plant is positive to contain saponin [10].

\section{Histochemical Test of Transverse Leaf Sections}

Leaf samples were cut into transverse section about 20-25 $\mu \mathrm{m}$ using microtome. The section was examined using reagents and then observed under Olympus BX51 microscope. Alkaloid content was examined using Bauchardat reagent. The positive result of alkaloid is indicated by the presence of reddish brown or yellow [11].

\section{RESULT AND DISCUSSION \\ Phytochemical Analysis}

The result of this study revealed 8 toxic Plants that usually utilizes by local people. They are bedor (Girardinia palmata), terpasan merah (Cestrum elegans), terpasan kuning (Cestrum elegans), jarak (Ricinus communis), kecubung putih (Brugmansia suaveolens), kecubung kuning (Brugmansia suaveolens), ciplukan (Physalis peruviana), and Kembang kudis (Euphorbia pulcherrima). The toxic parts and the symptoms of poisoning of the plants mentioned above is presented in Table 1 . The results of phytochemical screening on plants considered to be toxic by the Ngadiwono villagers are presented in Table 2.

Phytochemical tests performed are qualitative, so that the results only able to describe the group of substancess without more specific information about the type and concentration of secondary metabolite. Alkaloid test on jarak seeds (Ricinus communis) produces more alkaloid precipitate according to Gupta [12], risins, such as toxalbumin, phorbol, and cyanic acid. Kecubung (Brugmansia suaveolens) contains alkaloid scopolamine [13].

The results of phytochemical screening showed that all toxic plants mentioned by local people contained alkaloid substancess. Petersen [14] described several types of alkaloid substancess based on the structure of the molecular ring as well as 12000 alkaloid chemicals. Each alkaloid substancess will cause different symptoms of poisoning. The general symptoms of alkaloid poisoning were fever, anxiety, dilated pupils, reddened skin, dry skin, hallucinations and gastrointestinal symptoms. That symptoms could be occurred in both human and livestock. The screening results also found steroids and terpenoids in the toxic plants. Previous study stated that all those substancess are toxic to stomach [15]. 
Table 1. List of Toxic Plant and Symptoms of Poisoning

\begin{tabular}{|c|c|c|c|c|}
\hline Common Name & Scientific Name & Family & Toxic Parts & Symptoms of Poisoning \\
\hline Bedor & Girardinia palmata & Urticaceae & $\begin{array}{l}\text { Thorns at leaves } \\
\text { and stems }\end{array}$ & $\begin{array}{l}\text { Burning sensation in } \\
\text { the skin. }\end{array}$ \\
\hline Terapasan Merah & Cestrum elegans & Solanaceae & $\begin{array}{l}\text { Stems, leaves, and } \\
\text { flowers }\end{array}$ & $\begin{array}{l}\text { Abdominal bloating and } \\
\text { death in livestock. }\end{array}$ \\
\hline Terpasan Kuning & Cestrum elegans & Solanaceae & $\begin{array}{l}\text { Stems, leaves, and } \\
\text { flowers }\end{array}$ & $\begin{array}{l}\text { Abdominal bloating and } \\
\text { death in livestock. }\end{array}$ \\
\hline Jarak & Ricinus communis & Euphorbiaceae & Leaves and seeds & $\begin{array}{l}\text { Abdominal bloating in } \\
\text { livestock. Seeds cause } \\
\text { hallucinations in hu- } \\
\text { man. }\end{array}$ \\
\hline $\begin{array}{l}\text { Kecubung putih } \\
\text { bunga tidak } \\
\text { rangkap/kecubung } \\
\text { hitam }\end{array}$ & Brugmansia Suaveolens & Solanaceae & Leaves, seeds & $\begin{array}{l}\text { Abdominal bloating in } \\
\text { livestock. Seeds cause } \\
\text { hallucinations in hu- } \\
\text { man. }\end{array}$ \\
\hline Kecubung Kuning & Brugmansia Suaveolens & Solanaceae & Leaves, seeds & $\begin{array}{l}\text { Abdominal bloating in } \\
\text { livestock. Seeds cause } \\
\text { hallucinations in hu- } \\
\text { man. }\end{array}$ \\
\hline Ciplukan & Physalis peruviana & Solanaceae & Leaves & $\begin{array}{l}\text { Abdominal bloating in } \\
\text { livestock. }\end{array}$ \\
\hline Kembang kudis & Euphorbia pulcherrima & Euphorbiaceae & Stem sap & Itching on exposed skin. \\
\hline
\end{tabular}

Table 2. Phytochemical Identification Result of Secondary Metabolite Substances in Toxic Plants at Ngadiwono village

\begin{tabular}{|c|c|c|c|c|c|c|}
\hline \multirow{2}{*}{ Common Name } & \multicolumn{6}{|c|}{ Secondary Metabolite Substances } \\
\hline & Alkaloids & Flavonoids & Tannins & Steroids & Terpenoids & Saponins \\
\hline Bedor & + & - & - & + & - & - \\
\hline Terpasan Merah Leaves & + & - & - & + & + & - \\
\hline Terpasan Kuning Leaves & + & + & - & + & - & - \\
\hline Jarak Leaves & + & - & - & + & - & - \\
\hline Jarak Seeds & ++ & - & - & - & + & - \\
\hline Kecubung Putih Leaves & + & + & - & + & + & - \\
\hline Kecubung Putih Seeds & ++ & - & - & + & + & - \\
\hline Kecubung Kuning Leaves & + & - & - & - & + & - \\
\hline Kecubung Kuning Seeds & ++ & - & - & - & + & - \\
\hline Ciplukan Leaves & + & - & - & + & + & - \\
\hline Kembang Kudis Leaves & + & - & - & - & + & - \\
\hline
\end{tabular}

Note: presence (+); plentiful (++); and absence (-)

\section{Histochemical Analysis of Toxic Plant}

The result of this study showed that several plants cause different poisoning symptoms. Bedor has thorn that causes itching if touched by the skin. Previous study by Hidayat also revealed that Urtica Family, such as Bedor, have trichomes specialized into hair that could induce itchiness [16]. Trichome are made up of long, broad-based cells that swell, narrowed, and pointed for its top (Figure 1). The tapered end wall contains silica, while the lower part contains calcium. If it is touched, the rounded part on the end of tapered part will break at the boundary are, and the pointed part will be easily cut through the skin and then the chemical substances (histamine and acetylcholine) will cause itchiness.
Histochemical identification of Brugmansia suaveolens leaves found alkaloid substances at the trichome of capitate gland. The trichome of capitate gland comprised of 1 to 2 head cells with varying stalks, from the shortest until the longest contained 1 to 3 cells. That results also found in various plant species, such as Lavandula pinnata L. [16]. Trichome cells at peltate and capitate glands in $T$. quinquecostatus secretes substances that is similar to alkaloids [17]. On the leaves of Physalis peruviana, trichomes of uniseriate gland was found to be containing alkaloid. Alkaloid substances is found at the cross-sectional of Cestrum elegans leaves (yellow flower) in the secretory epidermis. In contrary, Cestrum elegans leaves (red flower) did not have it. 
According to the result of phytochemical test, Cestrum elegans leaves contained alkaloid substances. In contrary, histochemical result did not detect any alkaloid compond in the plant's tissue. The presentage of metabolite concentra-tion is predicted to be increasing along with the growth of the plants. However, adult organs have higher concentration compared to old organs that is experiencing degradation on its secretion structure [18]. Leaves samples used in this study did not collected based on the leaves age, so it affected the substances concentration in each
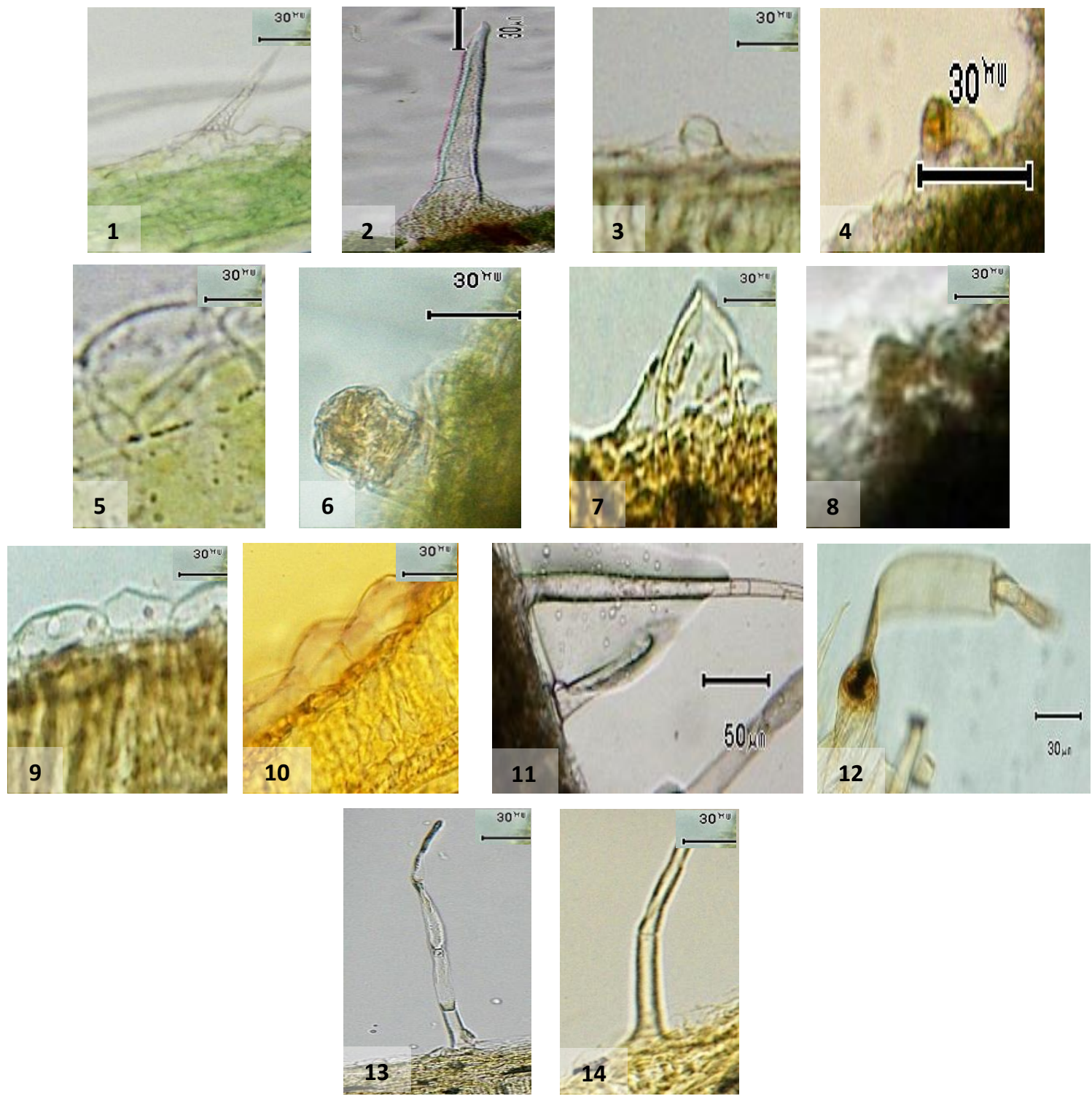

Figure 1. Histochemical Screening on the Leaves Trichome

\section{Description:}

(1) Control and (2) Alkaloid test, Girardinia palmata

(3) Control and (4) Alkaloid test, B. suaveolens (white)

(5) Control and (6) Alkaloid test, B. suaveolens (white)

(7) Control and (8) Alkaloid test, C. elegans (yellow)
(9) Control and (10) Alkaloid test, C. elegans (red)

(11) Control and (12) Alkaloid test, P. peruviana

(13) Control and (14) Alkaloid test, E. pulcherrima 
In addition, secretions also included substances that are the final product of metabolism or not the final product, but can not be used or only half of it that can be used physiologically (alkaloids, tannins terpen, harsa, and various crystals), or substances that physiologically functionate after secretion (enzyme, hormone). Secretion includes the release of material from the cell (either the surface of the cell or the space in the plants), or the accumulation of secretions in one part of the cell. Secretion in plants is usually produced in hair glands, tubes, and latisifer (sap cells, latex cells) [16].

\section{CONCLUSION}

Phytochemical screening test resulted that all toxic plants in this study contained alkaloid. While steroids found in G. palmata leaves, $C$. eleagans (yellow) leaves, C. elegans (white) leaves, $R$. communis leaves, $B$. suaveolens (white) leaves and seeds, and $P$. peruviana leaves. Terpenoid substances found in $C$. elegans leaves, $R$. communis seeds, B. suaveolens (white) leaves and seeds, B. suaveolens (yellow) leaves and seeds, and E. pulcherrima leaves. Flavonoids only found in terpasan kuning and kecubung putih leaves. According to histochemical test, trichome of toxic plant contained alkaloid, except for terpasan merah leaves (C. elegans).

\section{REFERENCES}

[1] Batoro, J. 2012. Etnobiologi masyarakat Tengger di Bromo Tengger Semeru Jawa Timur. PhD Thesis. Graduate Program, Bogor Agricultural University. Bogor.

[2] Yuliati, Y. 2011. Perubahan ekologis dan strategi adaptasi masyarakat di wilayah Pegunungan Tengger. University of Brawijaya Press. Malang.

[3] Ahmad, I., A. Faruq, O. Mohammad (Eds). 2006. Modern phytomedicine: turning medical plants into drugs. Wiley. Germany.

[4] Sembel, D.T. 2015. Toksikologi lingkungan dampak pencemaran dan berbagai bahan kimia dalam kedidupan sehari-hari. Andi Publisher. Yogyakarta.

[5] Heinrich, M., B. Joane, G. Simo, M.W. Elizabeth (Eds.). 2002. Farmakognosi dan fitoterapi. Syarief, R. Winny, A. Cucu, E. Ella, R. Euis, (Transl). EGC Medical Books Publisher. Jakarta.

[6] Department of Forestry. 1999. Potret desa penyangga Taman Nasional Bromo Tengger Semeru. Project Report on the Management Consolidation of Bromo Tengger
Semeru National Park 1998/1999. Bromo Tengger Semeru National Park. Malang.

[7] Alexiades, M.N., J.W. Sheldon. 1996. Selected guidelines for ethnobotanical research: a field manual. New York Botanical Garden. New York.

[8] Harborne, J.B. 1997. Metode fitokimia. Padmawinata, K., I. Soediro (Transl). Bandung Institute of Technology. Bandung.

[9] Jones, W.P., A.D. Kinghorn. 2006. Extraction of plant secondary metabolites. In: Sharker, S.D., Z. Latif, A.L. Gary (Eds). Natural Product Isolation, $2^{\text {nd }}$ Ed. Humana Perss. New Jersey.

[10] Indonesian Department of Health. 1995. Farmakope Indonesia. Department of Health. Jakarta.

[11] Farnsworth, N.R. 1996. Biological and phytochemical screening of plant. J. Pharm. Sci. 55(3). 225-276.

[12] Gupta, A., K. Alok, A. Ajay, A.V. Motoki. 2016. Acute accidental mass poisoning by Jatropha curcas in Agra, North India. Egypt. J. Forensic Sci. 6(4). 496-500.

[13] Gopel, C., C. Laufer, A. Marcus. 2002. Three cases of angel's trumpet tea-induced psychosis in adolescent substance abusers. Nord. J. Psychiat. 56. 49-52.

[14] Petersen. 2010. Common plant toxicology: A comparison of national and outhwest Ohio data trends on plant poisonings in the $21^{\text {st }}$ century. Toxycol. Appl. Pharmacol. J. 254. 148-153.

[15] Fahrauk, F., R. Julia,N. Neng. 2014. Uji bioaktivitas ekstrak daun dan fraksi daun kembang dayang (Cestrum nocturnum Linn.) terhadap Artemisia salina Leach dengan menggunakan Metode BSLT (Brine Shrimp Lethality Test). Proceeding of National Seminar on Science and Technology. Jenderal Achmad Yani University. 52-53.

[16] Hidayat, B. Estiti. 1995. Anatomi tumbuhan berbiji. Bandung Institute of Technology. Bandung. 74-75.

[17] Jing H., J. Liu, H. Liu, H. Xin. 2014. Histochemical investigation and kinds of alkaloids in leaves of different developmental stages in Thymus quinquecostatus. Sci. World J. 1-6.

[18] Werker, E., E. Putievsky, U. Ravid, N. Dudai, I. Katzir. 1993. Glandular hairs and essensial oil in developing leaves of Ocimum basilicum L. (Lamiaceae). Ann. Bot. 71. 4350. 